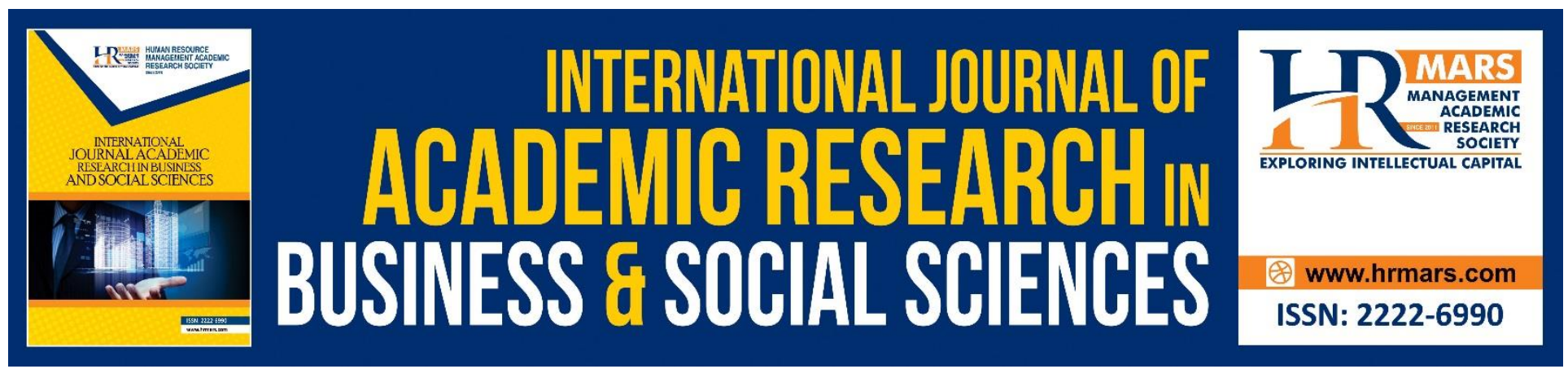

\title{
Impact of Feminism on the Progress of Contemporary Employment Culture
}

\section{Qaiser Mohi Ud Din}

To Link this Article: http://dx.doi.org/10.6007/IJARBSS/v9-i6/5921

DOI: 10.6007/IJARBSS/v9-i6/5921

Received: 02 April 2019, Revised: 11 May 2019, Accepted: 1 June 2019

Published Online: 25 June 2019

In-Text Citation: (Din, 2019)

To Cite this Article: Din, Q. M. U. (2019). Impact of Feminism on the Progress of Contemporary Employment Culture. International Journal of Academic Research Business and Social Sciences, 9(6), 58-68.

\section{Copyright: (C) 2019 The Author(s)}

Published by Human Resource Management Academic Research Society (www.hrmars.com)

This article is published under the Creative Commons Attribution (CC BY 4.0) license. Anyone may reproduce, distribute, translate and create derivative works of this article (for both commercial and non-commercial purposes), subject to full attribution to the original publication and authors. The full terms of this license may be seen

at: http://creativecommons.org/licences/by/4.0/legalcode

\section{Vol. 9, No. 6, 2019, Pg. 58 - 68}

Full Terms \& Conditions of access and use can be found at http://hrmars.com/index.php/pages/detail/publication-ethics 


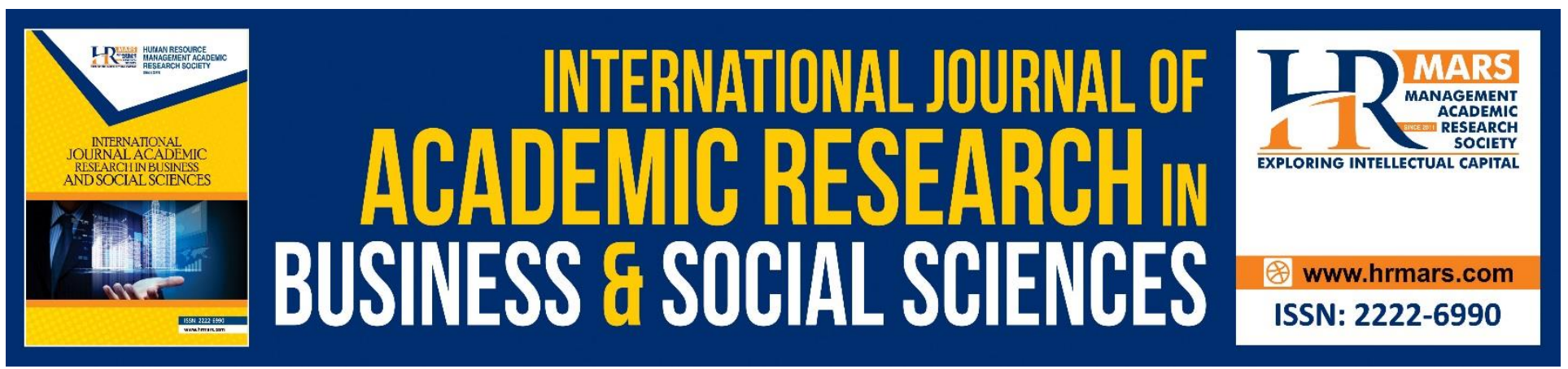

\title{
Impact of Feminism on the Progress of Contemporary Employment Culture
}

\author{
Qaiser Mohi Ud Din \\ National College of Business administration \& Economics Sub-Campus Bahawalpur \\ Email: Qaiser.mohi-ud-din@outlook.com
}

\begin{abstract}
Feminism plays a vital role in the workplaces around the globe and resulted in increased productivity due to the development of modern employment culture opted by successful organizations in the biosphere. This study is intended to examine the impact of feminism on development of modern employment culture of five multinational companies in Pakistan. Total 250 questionnaires were distributed and 200 respondents filled the questionnaire and response rate was eighty percent. By application of Statistical Package for Social Sciences (SPSS), descriptive statistics, correlation among variables, one-way ANNOVA and multiple regression analysis were carried out on the compiled data and concluded on the impact of selected independent variables including mental health, career fulfilment, equality and adversity on modern employment culture. The results showed that all the variables were significantly correlated to each other and had positive correlations. The regression analysis showed that there was a significant relationship among the independent and dependent variables.

In spite of advances for women in the modern employment culture, a few elements keep on contrarily sway women's' feeling of prosperity at work. These components incorporate gender discernment, gender job requirements, a male ruled work environment, and inflexibility. This section will survey ways a women's activist point of view may help them in the working environment by giving a challenge to contemporary role, giving a setting for segregation, and giving a feeling of competency in dealing with the workplace, maybe prompting a more noteworthy in general feeling of prosperity. In conclusion, utilizing the women's activist point of view, the section closes with certain suggestions for improving the work environment for women.
\end{abstract}

Keywords: Feminism, Modern Employment, Multinational Organizations.

\section{Introduction}

Feminism is one of the essential developments for human freedom. A feminist job in society is to effectively perceive the requirement for, and move in the direction of making balance for all women. 
INTERNATIONAL JOURNAL OF ACADEMIC RESEARCH IN BUSINESS AND SOCIAL SCIENCES Vol. 9, No. 6, June, 2019, E-ISSN: 2222-6990 @ 2019 HRMARS

Feminism is simply a development, which expects to illuminate individuals with an objective of improving sexual orientation fairness and fortifying women's status in society (Schneir, 1994) .

\section{Feminism and Contemporary Employment Culture}

Frenkel (2017) stated in his research work done related to feminism in employment culture of multinational corporations that the article expands upon late advancements in women's activist speculations as they were received in association concentrates to audit the condition of investigation into women in multinational corporations and to offer new headings for the investigation of multinational corporations as gendering associations, both as they are molded by gender orientation relations and are dynamic specialists in developing gender classifications, division of work, pictures, and imbalances. The article offers another plan for the investigations of corporate internationalization and its social outcomes.

Being feminist have enabled women to challenge this the norm of housework being ladies' work, and consequently both lessen the role of gender strain numerous ladies bear and increment prosperity. Research underpins this attestation in that libertarian frames of mind, a sign of women's liberation, are related with a progressively equivalent dissection of work of household (Cunningham, 2005).

Feminists have assumed a job in women acquiring the privilege to possess property, and the privilege to cast a ballot in 1920. Feminists have likewise extended regenerative rights and have passed laws to help shield women from abusive behavior at home and sexual maltreatment. Concerning conditions, feminists helped place a preclusion on sex separation into the Civil Rights Act, helped banning segregation in instruction, and have advocated parallel pay in the work environment. Furthermore, feminists restricted work victimization pregnant women, and assumed a key job in lawfully defining inappropriate behavior as an infringement of women's rights in 1980. Plainly women with feminist perspectives have just expanded the personal satisfaction among women and improve value in the work environment, making a more beneficial condition for women (Saunders, 2016).

Feminists endeavored numerous adjustments in the work environment to help facilitate the strain of the various jobs numerous women face, however their prosperity was constrained. Working environment flexibility was once contended to be a feminist answer for women's bustling lives and way moms could be better suited in the working environment. Nevertheless, work flexibility neglected to evacuate past models of business, and subsequently the working environment has rejected a few women from openings for work and security (Kathryn, 2013). Many studies have shown how feminist are influencing modern employment culture of organizations through their skills and work done positively but still there is need to give exposure to man force in Pakistan because of their typical thinking and still women facing issues in their work in form of inequality, mental health, career fulfilment and less adversity in organizations.

By addressing the latest issue, the findings of the study will not just cover the gap in the existing body of literature but also provide a framework, which can help the management of multinational companies for improvement in modern employment culture so women can give their best.

\section{Hypothesis}

H1- Feminism is significantly related to the progress of contemporary employment culture in multinational companies of Pakistan. 
INTERNATIONAL JOURNAL OF ACADEMIC RESEARCH IN BUSINESS AND SOCIAL SCIENCES

Vol. 9, No. 6, June, 2019, E-ISSN: 2222-6990 (C) 2019 HRMARS

H2- Equality is significantly related to the progress of contemporary employment culture in multinational companies of Pakistan.

H3- Mental health is significantly related to the progress of contemporary employment culture in multinational companies of Pakistan.

H4- Career fulfilment is significantly related to the progress of contemporary employment culture in multinational companies of Pakistan.

H5- Adversity is significantly related to the progress of contemporary employment culture in multinational companies of Pakistan.

\section{Literature review}

Researchers all over the world have carried out different studies to analyse and explore the effects of feminism on development of modern culture. In past few years, the rapid evolution of feminism has evoked the interest of researchers and hence extensive studies can be conducted for the analysis.

\section{Feminism and progress of contemporary employment culture}

Dimensions selected against feminism with respect to contemporary employment culture progress have been elaborated in detail below.

\section{Equality}

Ladies have a few difficulties with respect to disparity in the working environment. In the first place, there is a constant distinction in the income among ladies and men. Pay segregation is difficult to see on the grounds that examining pay is regularly met with objection. In this manner, ladies are every now and again unconscious that they are being paid not as much as men. In the event that ladies are uninformed of a compensation hole in the work environment, they don't question, and the issue is bound to proceed. Feminist imply that women experience the ill effects of segregation because of their gender and that the network needs to cooperate to advance equity among people ( Tyson, Zahidi, \& Hausmann, 2009).

There is likewise imbalance in the status of people in the working environment. Men hold the greater part of the most astounding places of intensity all through the world contrasted with women, and men are advanced quicker paying little respect to their execution assessment (Jenkins, Beehr, \& Gupta, 1983).

Be that as it may, look into on high-accomplishing ladies in the work environment demonstrates that fruitful ladies share numerous qualities with women's activist ladies. These qualities incorporate a higher confidence, high self-efficacy, Instrumentality/Masculinity and self-governance (Bono \& Judge, 2001).

\section{Career Fulfilment}

Women's liberation implies that we have to challenge conventional sexual orientation jobs, and ladies who are women's activist are bound to show more elevated amounts of Instrumental/Masculine and Androgynous (high in Masculinity and Femininity) attributes. Ladies who 
are progressively women's activist or potentially hermaphroditic are commonly less worried about sticking to society's pre-imagined ideas of sexual orientation proper professional decisions, subsequently opening up a more extensive exhibit of vocation decisions with the goal that they can find the calling that best suits them. It's especially critical that young ladies and ladies are available to the generally male commanded STEM fields, since STEM employments are the quickest developing area of occupations (Kashubeck-West \& Saunders, The relations among feminist identity development, gender-r ole orientation, and psychological well-being in women., 2006).

Kashubeck-West and Saunders (2006) states that research uncovers that sexual orientation based desires can affect confidence and the vocation alternatives of young ladies for an incredible duration.

\section{Mental Health}

In spite of the fact that exploration keeps on unfurling, it creates the impression that woman's rights and women's activist perspectives are useful for ladies and their psychological wellness. To start with, holding women's activist perspectives seems to decrease unwanted indications among ladies. For instance, look into uncovers a negative relationship among sadness and introduction to feminism (Mauthner, 1998). However, instead of essentially the nonappearance of trouble or negative effect, the idea of psychological wellness consolidates a decline in trouble with an expansion in prosperity, and research likewise proposes that woman's rights helps the emotional wellness of ladies. For instance, look into exhibits that ladies who are feminist or are presented to feminist perspectives experience a higher confidence and self-c onfidence just as expanded individual strengthening (Stake \& Malkin, 2004).

\section{Adversity}

Ladies with large amounts of feminist character are bound to distinguish segregation and perceive terrible encounters when they occur (Zucker, 2004).

Research shows that presentation to feminist perspectives expands a lady's self-confi dence, individual strengthening, and locus of control, giving feminists extra instruments to confront separation and sexism head on. Furthermore, inquire about uncovers that identifi cation as a feminist is emphatically corresponded with positive adapting aptitudes, for example, looking for help from others and going up against sexism (Arias \& Leaper, 2011).

Furthermore, ladies who recognize as feminist are more probable than non-feminist ladies to report sexism and separation (Friedman, 2009). 


\section{Theoretical Framework}

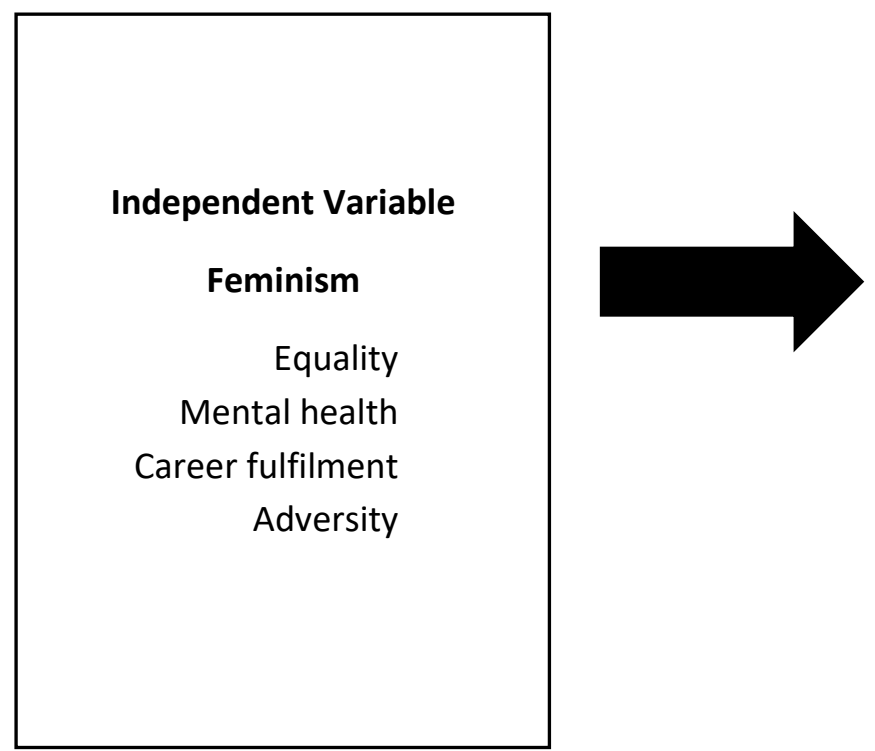

\section{Dependent Variable}

Contemporary Employment

Culture

Figure 2.1 Theoretical Framework of the Study

\section{Research Methodology}

For the purpose of research objectives to align with the methodology, Pragmatic approach was used in the study contextual. Primary data is used. As concern for primary study, a structured questionnaire was used for the objective of the current study. After developing the questionnaire, it was distributed to 250 female employees of selected multinational companies. Quantitative methodology is used. The results were predicted by use of SPSS.

\section{Findings}

Inferential Statistics

Reliability of the instrument

The reliability analysis of the variables was performed in SPSS and the result was as follows. The table depicts the cronbach's alpha values for the variables under study.

\begin{tabular}{|l|l|l|l|}
\hline No. & Dimension & No of items & Cronbach's alpha \\
\hline 1 & Equality & 3 & 0.772 \\
\hline 2 & Mental Health & 3 & 0.768 \\
\hline 3 & Career fulfilment & 3 & 0.761 \\
\hline 4 & Adversity & 3 & 0.750 \\
\hline 5 & Overall Reliability & 12 & 0.780 \\
\hline
\end{tabular}

Table 4.1 Reliability of instrument 
The results of the reliability analysis shows that all the variables for this study have a value of cronbach's alpha higher than 0.7, which is necessary for the instrument to be valid for a particular study. Cronbach's alpha is a measure of internal consistency in a given study. It identifies that how close are the items related to each other. Internal consistency is basically the measure of correlations between different variables in a given study. It is used to check that the items that are measuring a variable can produce linear results or not. The cronbach's alpha cannot be considered a statistical test, rather it is a coefficient of reliability which measures the consistency among various constructs. In the above table as the result depicts there are four independent variables. All the variables have a high reliability with the highest reliability of equality. The overall reliability of these variables is also measured and the cronbach's alpha value of overall reliability is 0.780 which is also on the higher side.

\section{Correlation Analysis}

For examining the level of correlation between and among the variables we have performed the test on data which is as follows:

\begin{tabular}{|l|l|l|l|l|l|}
\hline & Equality & $\begin{array}{l}\text { Mental } \\
\text { Health }\end{array}$ & $\begin{array}{l}\text { Career } \\
\text { Fulfilment }\end{array}$ & Adversity & $\begin{array}{l}\text { Modern } \\
\text { Employment } \\
\text { Culture }\end{array}$ \\
\hline Equality & 1 & $.221^{* *}$ & $.579^{* *}$ & $.389^{* *}$ & .752 \\
\hline Mental Health & $.221^{* *}$ & 1 & $.112^{*}$ & $.582^{* *}$ & .616 \\
\hline Career Fulfilment & $.579^{* *}$ & $.112^{*}$ & 1 & $.238^{* *}$ & .459 \\
\hline $\begin{array}{l}\text { Adversity } \\
\text { Modern } \\
\text { Employment } \\
\text { Culture }\end{array}$ & $.389^{* *}$ & $.582^{* *}$ & $.238^{* *}$ & 1 & .554 \\
\hline
\end{tabular}

Table 4.2 Correlation Matrix

The results indicated that variables are correlated with each other in a positive manner. A positive correlation was found among variables, which are in line with the hypothesis of this study. For example if high positive correlation is found among adversity, it will have positive impact on modern employment culture of 0.752 , which falls in between -1 and +1 . This indicates that if adversity increases positive affect modern employment culture increases too and a linear relationship would develop between the two. The significance value in this case is 0.00 , which is less than 0.05 , which indicates that adversity and modern employment culture are significantly correlated with each other. It also signifies that part of the hypothesis, which explains that there is a noticeable relationship between adversity and modern employment culture. 
A high positive correlation is noticed between the relationship of mental health and modern employment culture with a value of 0.616. The significance value is also 0.00 which is less than 0.05 . It also indicates that the mental health and modern employment culture are largely correlated with each other and as value of mental health increases value of modern employment culture increases along with the fact that they have a significant relationship with each other.

The moderate and positive relationship between career fulfilment and modern employment culture with a value of 0.459 and since the significance or $p$ value is less than 0.05 there is a moderate and significant correlation between the two variables, which makes career fulfilment independent and modern employment culture dependent variable. The consistence relationship between equality and modern employment culture is significant with a value of 0.579 , which is on the moderate side.

The other independent variables and the dependent variables among the correlation were also measured. The variables are significantly and positively correlated in correlational analysis and in such relationship if one variable increases the other one will also increase but in the same direction so to say that the variables for this study have a linear relationship with each other. The independent variables are correlated positively with dependent variable.

\section{Multiple Regression Analysis}

Regression analysis was applied to find out the relationship between dependent and independent variables for this study.

\section{Regression Results}

\begin{tabular}{|l|l|l|}
\hline \multicolumn{2}{|l|}{ Model Summary } & \\
\hline No. & Items & Values \\
\hline 1 & R & 0.838 \\
\hline 2 & R Square & 0.801 \\
\hline 3 & Adjusted R Square & 0.729 \\
\hline 4 & F-Value & 9.14 \\
\hline 5 & Sig ( p-value) Anova & 0.002 \\
\hline 6 & Durbin-Watson & 1.21 \\
\hline \multicolumn{2}{l}{ a. } & Dependent Variable: Modern employment culture \\
b. & Predictors: (Constant), DV, CF, MH, AD & \\
\hline
\end{tabular}

Table 4.3 Regression result

The above results show the values of $\mathrm{R}$, $\mathrm{R}$ square, Adjusted $\mathrm{R}$ Square, F-value and the Sig value derived from the analysis of variance table (anova table). Regression results of all selected MNCs showed that the overall model of the feminism determinants and modern employment culture are significant as the $p$-value is $0.000<0.05$. Moreover, the test of Durbin Watson also showed no autocorrelation within the residuals of the model as the value stood as 1.21 . The $\mathrm{R}^{2}$ value or the $\mathrm{R}$ Square value shows the total amount of variation in the dependent variable that can be explained by the independent variables Adding to the effectiveness of models, the best fit of data was also determined by the values of R-square for 0.801 in along with Adjusted R-square values at 0.729 that are heading towards the standard value set of 1 . This notifies that the explanatory variables are significantly impacting on the 
INTERNATIONAL JOURNAL OF ACADEMIC RESEARCH IN BUSINESS AND SOCIAL SCIENCES

Vol. 9, No. 6, June, 2019, E-ISSN: 2222-6990 ㄷ 2019 HRMARS

modern employment culture of multinational companies used for this study. The F-value or the Fstatistics has a value of 9.14 and the sig ( $p$ value) obtained from the anova output is 0.000 which states the good fit of the model.

\section{Coefficient Results}

The coefficients table is shown below and the results are discussed in detail.

Coefficients $^{\mathrm{a}}$

Table 4.4 Coefficient results

\begin{tabular}{|c|c|c|c|c|c|c|}
\hline \multirow{2}{*}{\multicolumn{2}{|c|}{ Model }} & \multicolumn{2}{|c|}{$\begin{array}{l}\text { Unstandardized } \\
\text { Coefficients }\end{array}$} & \multirow{2}{*}{$\begin{array}{l}\text { Standardized } \\
\text { Coefficients } \\
\text { Beta }\end{array}$} & \multirow[b]{2}{*}{$\mathrm{t}$} & \multirow[b]{2}{*}{ Sig. } \\
\hline & & B & $\begin{array}{l}\text { Std. } \\
\text { Error }\end{array}$ & & & \\
\hline & (Constant) & -.760 & .991 & & -.780 & .610 \\
\hline & $E Q$ & .333 & .080 & .420 & 4.688 & .000 \\
\hline & $\mathrm{MH}$ & .270 & .088 & .399 & 3.520 & .000 \\
\hline & CF & .444 & .091 & .467 & 4.917 & .000 \\
\hline & $A D$ & .271 & .074 & .237 & 3.824 & .000 \\
\hline
\end{tabular}

In the above tables the unstandardized coefficients indicates the level of variance in the dependent variable with an independent variable when all other independent variables are held constant. From the results of table 4.4, it can be interpreted that for a similar increase in equality there is an increase of 0.333 in the level of modern employment culture. Similarly it can be interpreted that for a similar increase in the levels of mental health there is 0.384 level of increase in modern employment culture. It can be seen that for all the independent variables $(p<0.05)$. It shows that there is a significant effect of these independent variables on the dependent variable modern employment culture.

Likewise, from the results of above table, it can be interpreted that all the independent variables had $\mathrm{p}<0.05$ and so had a significant relation with the dependent variable. In this way $\mathrm{H}: 1, \mathrm{H}: 10$ were accepted and their null hypothesis were rejected. The overall results showed that there was a significant relationship between the independent variables and the dependent variables i.e. accepting $\mathrm{H}: 1$ to $\mathrm{H}: 10$.

\section{Conclusion and Recommendations Conclusion}

This research focused on the progress of contemporary culture in MNCs in Pakistan. The current chapter is summing up all the results which were retrieved from the data is to say that there is positive impact of feminism on progress of contemporary culture in MNCs. 
In short, albeit extra research is required, it shows up ladies who are progressively feminist may arrange all the more decisively at work for a higher compensation, just as champion themselves at home so there is a superior equalization in housework and childcare among them and their life partners. Furthermore, women who are feminist are bound to break outside customary gender jobs to find a vocation that is the best fit for them, notice and report gender separation in the working environment, and work together to inspire change in the work environment where it is required. These characteristics can improve the home and work life of women and increment psychological wellness and employment fulfilment. Be that as it may, as is confirm in recently referred to information and research, there is still more work to be finished. On the off chance that women accomplish balance in the work environment, it might be after there is purposeful mediation in the work setting. Accordingly, the following passages are suggestions to improve the working environment for women.

\section{Recommendations}

For change in the working environment to happen, females should be heard. Businesses should be proactive in including women on sheets and advisory groups that talk about the workplace. Even better, we need progressively female ranking directors and administrators in enterprises to be pioneers for balance among people just as family-accommodating strategies and techniques. Having females at the table enables the workforce to become acclimated to hearing females' voices and points of view when all is said in done, and females' very nearness can change desires and enlarges the group of partners.

The work environment could likewise make changes to turn out to be even more family benevolent and facilitate representatives' work and family lives. Adaptable booking, the capacity to telecommute or working from home, and friends help with childcare should all be considered among associations, and the progressions would be useful to the both women and men alike.

Talking about compensations with collaborators when fitting may likewise push females to figure out in the event that they have been casualties of separation.

Any or the majority of the above changes to the work environment would probably build work fulfilment, steadfastness, and profitability, and just with activities, for example, these will we see a positive, verifiable change in the lives of working females. 
INTERNATIONAL JOURNAL OF ACADEMIC RESEARCH IN BUSINESS AND SOCIAL SCIENCES

Vol. 9, No. 6, June, 2019, E-ISSN: 2222-6990 (C) 2019 HRMARS

\section{References}

Cunningham, M. (2005). Gender in cohabitation and marriage - The infl uence of gender ideology on housework allocation over the life course. Journal of Family Issues, 26, 1037-1061.

Frenkel, M. (2017). Gendering the MNC. Multinational Corporations and Organization Theory: Post Millennium Perspectives, 49, 357-388.

Friedman. (2009). Individual and situational factors related to young women's likelihood of confronting sexism in their everyday lives. Sex Roles, 61, 449-460.

Jenkins, B. \& Gupta. (1983). Employee gender, gender similarity, and supervisor- subordinate cross evaluations. Psychology of Women Quarterly, 8, 174-184.

Kashubeck-West, \& Saunders. (2006). The relations among feminist identity development, gender-r ole orientation, and psychological well-being in women. Psychology of women, 30, 199-211.

Kashubeck-West, \& Saunders. (2006). The relations among feminist identity development, gender-r ole orientation, and psychological well-being in women. Psycology of Women, 30, 199-211.

Kathryn. (2013). A feminist response to late twentieth-century capitalism? Feminist Media Studies, $13,395-414$.

Mauthner. (1998). It's a women's cry for help: A relational perspective on postnatal depression. Feminism and Psychology, 8, 325-355.

Saunders, K. (2016). Women in the Workplace: Feminism's Potential Impact. International Handbooks of Quality-of-Life. Springer, Dordrecht, 565-575.

Schneir, M. (1994). The Vintage Book of Feminism . London.

Stake, \& Malkin. (2004). Changes in attitudes and self-confi dence in women's and gender studies classroom. Sex Roles, 455-468.

Tyson, Z. \& Hausmann. (2009). The global gender gap report . . World Economic Forum.

Zucker. (2004). Disavowing social identities: What it means when women say, "I'm not a feminist, but. Psychology of women, 423-435. 